\title{
TÉRBELI-TÁRSADALMI ÁTALAKULÁS, SZOCIÁLIS VÁLSÁG ÉS VÁLSÁGKEZELÉS MISKOLC ÉS ÓZD GETTÓSODÓ VÁROSRÉSZEIBEN
}

\author{
HALÁSZ LEVENTE \\ SOCIAL-SPATIAL TRANSFORMATION, SOCIAL CRISIS \\ AND CRISIS MANAGEMENT IN NORTHERN HUNGARIAN \\ URBAN GHETTOS - THE CASES OF MISKOLC AND ÓZD
}

\begin{abstract}
In spite of the great multitude of regional and urban development interventions, urban ghettos as particular spaces of social and/or ethnic segregation have remained integral segments of socio-spatial structures of the rural hinterland of Northern Hungary since the regime change. Different social, economic, environmental, political and cultural factors have contributed to one of the deepest and most complex socio-structural crises in Hungary. Over the past quarter century, despite significant public and even EU financial support, the Roma and the extreme poor have experienced very little development in terms of their living standards. This improvement is still far from the average quality of life concerning low and low-middle strata people. Even though local governments have made steps towards mitigating the seriousness and extreme homogeneity of ethnic and/or poverty ghettos in recent decades. This could have been achieved due to urban regeneration projects, including de- and anti-segregation. These have involved the demolition of ghettos and the displacement of a large proportion of the extreme poor living in misery. The 'spectacular' results that might be observed in these areas have been overshadowed by the fact that ethnic-based ghettoization has not decreased significantly in the region for more than three decades. Instead, only its patterns have changed. Segregation, in fact, still persists, though in a modified form. Some of the notorious urban ghettos located in the vicinity of the city center have disappeared, and thus poverty has been 'swept away' from these areas. They were replaced by larger number of spatially fragmented, ethnically similar homogeneous neighborhoods. In the end, the conflicts still exist in different intra-regional and intra-urban contexts, mostly in some secluded spots of the rural countryside - far from social scientific observation and media attention. The emergence of these 'islands of extreme poverty' provide evidence of not one, but rather several parallel social realities in Hungary. These ghetto spaces are so different from mainstream ones that they might accurately be called 'Another Hungary'.
\end{abstract}

Keywords: urban ghetto, segregation, social (in)justice, extreme poverty, urban rehabilitation

\section{Bevezetés}

A tanulmány a Miskolcon és Ózdon található gettósodó városrészek rendszerváltozás óta zajló társadalmi folyamatait, a kialakult szociális válságot, illetőleg arra válaszul válságkezelési beavatkozásokat mutat be. Az egykoron fontos ipari központok a szocializmus csúcsteljesítményei, az akkori fejlesztéspolitika iskolapéldái voltak: Építésük volumene kivételesen nagy ívú Magyarország egyéb iparvárosaival összevetve. Ugyanakkor példátlan mélységú az a szerkezeti válság is, amelyet a rendszerváltozás keretében történt társadalmi, gazdasági, politikai átalakulások következményeként elszenvedtek. Stigmatizált településekké váltak. (Amely helyzet a média több évtizedes negatív sztereotípiákat erősítő hatásának egyaránt felróható.) Neveik három évtizede összekapcsolódtak az etnikai színezetet (is) kapó szegénységgel és búnözéssel, a nyomorukat generációkról generációkra tovább örökített, gettókba kényszerült emberek sorstalan élethelyzetének látványával. Feszültséggel teli leszakadó roncstársadalmak jöttek létre. Olyannyira, hogy magyarországi 
összehasonlításban gyakorlatilag egyedülálló társadalmi és szociális válsággal kénytelenek megküzdeni-előzetes tapasztalatok és megfelelő eszközök hiányában. Jelen írással célom kettős. Egyrészt a gettósodás folyamatát, a gettók kialakulásának lépcsőfokait, azok történeti fejlődését, döntően a gettókra (úgy, mint a koncentrált szegénység tereire) jellemző társadalmi jelenségeket mutatom be. Másrészt Miskolc és Ózd jelenleg létezô, a közeli vagy a távolabbi múltban felszámolt, már rehabilitált, rehabilitáció alatt álló, vagy rehabilitációra váró gettói kerülnek elemzésre. Méghozzá a részben vagy egészben eredményes beavatkozások menete, azok társadalmi következményei tükrében. Módszertana úgyszintén kettôs. A témával foglalkozó magyar, valamint nemzetközi szakirodalom másodelemzése megtörtént. Ezeket 2016 és 2018 között Borsod-Abaúj-Zemplén megye több iparvárosában lefolytatott előzetesen validált, félig strukturált interjúk $(\mathrm{N}=39)$ következtetései egészítették ki. Az interjúalanyok a települések véleményformálói (városvezetők, polgármesteri hivatal irodavezetői, egyházi vezetôk, kisebbségi önkormányzatok vezetői, szociális szféra hivatalos alkalmazottai, általános- és középiskolai tanárok, civil szervezetek vezetői, rajtuk kívül pedig a térséget és/vagy a témát kutató szakemberek (egyetemi oktatók, társadalomtudósok). A cikkben olvasható kutatási eredmények a tanulmány szerzőjének 2018-ban megjelent „Városfejlődési pályák és válságkezelési alternativák-Miskolc, Ózd és Kazincbarcika rendszerváltozás utáni társadalmi, gazdasági és térszerkezeti átalakulása" címú doktori értekezésén alapulnak.

\section{A gettók kialakulása és belső átalakulási folyamatai}

A kapitalista térhasználat elkerülhetetlen velejárója, hogy a piacgazdaság az eltérő jövedelemmel rendelkező csoportok számára különböző helyeket jelöl ki (HARVEY, D. 1973; BODNÁR J. 2001), ahol koncentrálódásuk szintje gyors ütemben nő, míg a szomszédos térbeli egységek közötti különbségek élesednek. A szegregáció kialakulásában nagy szerepet játszik az elmosódott társadalmi távolságok egyértelmú térbeli távolságokkal történó kompenzálása, ezáltal pedig a státusz béli pozíciók láthatatlan rendszere fellazul (Sommer, R. 1969). Szociáldarwinista értelemben a szegregáció az által válik jelentőssé és látványossá, ha a vagyoni helyzet kimutatása a szegények felé a kiváltságos státuszcsoportokról „rossz lelkiismerettel” párosul és az alacsonyabb társadalmi csoportok közelsége félelmet ébreszt bennük (HARVEY, D. 1973; GyURIS F. 2014). Itt érdemes említést tenni a „kettős városról” (Dual City) vagy „,kétsebességes városról” (Twospeed City), amelyek a későkapitalista városok szinonimájaként is értelmezhetők. A globalizációnak köszönhetően világszerte a II. világháború óta nem tapasztalt mértékú társadalmi polarizáció sújtja a városi tereket (CASTELLS, M. 1995; SASSEN, S. 2000). A jelenség a kapitalista világ városait főként a nyolcvanas évek eleje óta, míg az egykori Keleti Blokk államait a rezsimváltások idejétől, az ennek hatására elhatalmasodó válságok következményeiként jellemzi. A társadalmi és gazdasági folyamat két ellentétes jelenség eredménye; egyfelól a munkaerő-piac stabilitása meggyengült, a szürke- és feketegazdaság teret nyert és a szegénység általánossá vált. Másrészről nagy számban megjelent a globalizáció lehetóségeit meglovagló „,nouveaux riches”, tehát az újgazdag réteg. A kettős városok jellemvonása az egyre szúkülő középosztály, ezzel párhuzamosan a vagyonos magas státuszú réteg kisebb mértékü, míg az alacsony státuszúak látványos megerösödése. Emellett a nehézipar leépülésével, elsősorban jelentős iparvárosokban a társadalmi hierarchia alján megjelent a „nouveaux pauvres”, az újszegény réteg, tehát a munkájukat és egzisztenciájukat elvesztő egykori munkások tömegei és azok családjai. Ezekben a városokban nincs látványos átmenet az alacsony és magas státuszcsoportok által lakott településrészek között. 
Sőt, előfordulnak esetek, amikor egymás közvetlen közelségében jönnek létre a luxus és a nyomor szigetei.

A társadalom peremére kerülés, tehát a marginalizáció fó okai az elszegényedés, az egyenlőtlenségek növekedése, a diszkrimináció (pl. etnikai), a munkaerő-piaci kiilleszkedés, a kapcsolati rendszerek szétzilálása és megszúnése (FERGE Zs. 2000; LADÁNYI J.-VIRÁG T. 2009). Ezek a társadalmi jelenségek lakóhelyi szegregációhoz, majd erősödő gettósodáshoz vezetnek. A településeken belüli koncentrált szegénység és ezzel összefüggő lakóhelyi szegregáció bizonyos tekintetben spontán társadalmi történés, melynek kialakulásáért és fennmaradásáért számos társadalmi, gazdasági, civilizációs és kulturális tényező együttesen felelős. (Kolosi T. 2000; LADÁNYi J. 2012; RóBERT P. 2013; FERGE Zs. 2017).

Maga a gettósodás a késómodern társadalmak fragmentálódásának és a társadalmi egység szétesésének, csonka társadalmak létrejöttének következménye. Terület-specifikus értelemben azokat a településeket, településrészeket nevezzük így, amelyek lakosai kulturális és etnikai szempontból homogének, ugyanakkor szociálisan hátrányos helyzetúek, a társadalom számára pedig marginalizáltak (JARY, D.-JARY, J. 1991). Szociáldarwinista értelmezésben a többségi társadalom felőli olyan szisztematikus kulturális és fizikális kirekesztési folyamatként jelentkezik, amely következtében a - szerintük - közéjük nem tartozó csoportokat létminimum alatt élő, etnikai kisebbségek által lakott, erőteljesen szegregálódó városrészekbe szorítanak. A folyamat sajátos belső logikával rendelkezik, sőt, az ott élők önmagát beteljesíto jóslatainak spiráljaként is felfogható. WACQUANT, L. (2004) definíciója szerint a gettók kialakulását és dinamikus fennmaradását négy tényező befolyásolja: (1) Az adott társadalmi csoport stigmatizációja (kategorizálás). (2) Teruileti kirekesztése (szegregáció - szeparáció), tehát a terület élesen elválik a település többi részétől, avagy a település a szomszédos települések közül. (3) Társadalmi kirekesztése (diszkrimináció), ennek értelmében az itt élők nem önszántukból, hanem gazdasági, adminisztratív, szimbolikus kényszer hatására különülnek el. Végül (4) a többségi társadalomtól eltérō, párhuzamos intézményrendszer használata. Napjainkra a közösségi kapcsolatok és intézményrendszer átalakulásával, redukálásával a puszta létfenntartás és folytonos küzdelem közömbös tereivé válnak (WACQUANT, L. 1999). Az ország etnikailag szegregált települései és településrészei folyamatos változáson mentek és mennek keresztül. A társadalmilag heterogén, elmosódott etnikai határokkal jellemezhető szomszéd ságtól az etnikai koncentráció, a munkaerőpiacról történő kiilleszkedés, a generációkon át öröklődo nyomor által jellemezhető, fizikai és szimbolikus határokkal elkülönülő gettóig terjedő kontinuumon belül.

Elsősorban perifériális elhelyezkedésü aprófalvak és a gazdasági szerkezetválságból nehézkesen kievickélö egykori iparvárosok, városrészek válnak etnikai és szociális gettókká újabb és újabb munkaerő-piacról kirekesztett, vagy legális munkát sosem végző, alacsonyan képzett generációk felnövekedésével. Ezeket a településeket, településrészeket etnikailag homogén, szélsöségesen szegregált, differenciált státuszhelyzetú gettók jellemzik. Az itt élő deprivált családokat/egyéneket a nyomor, az anyagi ellehetetlenülés (alacsony jövedelem, csekély vagyon, jövedelemtermeló képesség hiánya, hitelcsapda), főként a gyermekek civilizált világhoz méltatlan esélytelensége mellett az etnikai diszkrimináció különböző formái is sújtják (Ferge Zs. 2000; VÁRADI M.M.-VIRÁG T. 2014; PÁsZTOR I.Z.-PÉnZES J. 2018). Ezt a rendszerváltozás óta mélyülő szociális válsághelyzetet súlyosbítja a jogilag és etikailag megkérdőjelezhető, felülről irányított tudatos népesség-átrendez(őd)és. Ezeken a településeken ugyanis évtizedek óta hajtottak és jelenleg is hajtanak végre deszegregációs és városrehabilitációs beavatkozások „,börébe bújtatott” gettófelszámolási programokat. Ennek eredményeként a társadalom legalján elhelyezkedő szegény, döntően cigány származású lakosságot gettósodó aprófalvakba, vagy kedvezőtlen társadalmi és gazdasági szerkezetű városok nyomortelepeikre ,terelik át/vissza”. Ezáltal a probléma nem oldódik 
meg, csupán áthelyezik másik földrajzi térbe, illetôleg mélységében és tulajdonságaiban változik. Az említett beavatkozási lánc vált az elmúlt közel három évtized magyarországi „szegénységpolitikájának” lényegi eszközévé. LADÁNYI és SZELÉNYI (2014) szerint a folyamat legfőbb veszélye, hogy a mélyszegénységből a sikeres integráció útjára lépett, a társadalmi hierarchia alsó fokáról magát feljebb küzdő (középosztályosodó?) embereket is visszalöki etnikailag homogén, gettósodó településekre (gyakran zsákfalvakra) és városi szegénytelepekre.

A posztszocialista országokban gyakorlatilag ugyanazon forgatókönyv alapján gettósodtak el egyes települések, településrészek: 1990 előtt az etnikai összetétel, a társadalmi státusz tekintetében heterogénebb településeken élő középosztályosodó, vagyonosodó családok általában úgy költöztek egyre jobb lakásokba, hogy a területen belül változtatták lakóhelyüket. A rendszerváltozás után azonban sok helyütt a jövőbeni munka, oktatás, képzés, kultúra, szabadidő lehetőségeinek szúkölése miatt a társadalmi ranglétrán feljebb kerülő felső- és középső státuszba tartozó családok - beleértve a cigányságot is - növekvő számban és végérvényesen hagyták el a slumosodó, tehát zsúfolt, lepusztult épületállománnyal rendelkező, társadalomszervezési hiányossággal küzdő környékeket. Ritkább esetben a város magasabb státuszúak által lakott (elit szegregáció) részeibe költöztek, általánosságban viszont a térséget is maguk mögött hagyták. A folyamat önmagát gerjesztette, a gettósodás mértékének növekedésével már a közepes, ső́t az alatti társadalmi státuszú családok és egyének is az ország más részeiben, illetőleg külföldön kerestek megélhetést. Az említett folyamat, tehát a társadalmi rezidualizáció következtében fokozódott a mélyszegénységben, kilátástalanságban élö, többségében cigány családok koncentrációja (LADÁNYI J.-VIRÁG T. 2009). A szegények szegregátumai - kiváltképp a legroszszabb szocioökonómiai helyzetűek - területein nem csak fizikai környezetükben, hanem belső társadalmi viszonyaikban is a gettósodás jeleit mutatják. Itt az általános társadalmi értékek és szabályok hatályukat vesztik, valamint kialakul egy belső szabályozók alapján múködő szubkultúra. Ezekben a gettósodó városrészekben, negyedekben, szomszédságokban alacsony komfortfokozatú lakások jellemezték a területeket és végleg elfogytak azok a többé-kevésbé konszolidált körülmények között élő társadalmi csoportok, amelyek az így támadt ûrt betölthették volna. A népességük jelentős részét elvesztő, szerepkör nélküli „bukott” településrészeken az ingatlanárak jelentős mértékben csökkentek (a kereslethiány miatt tulajdonképpen megszúnt az ingatlanpiac), a megüresedő házak eladhatatlanná váltak. Számos család kényszerúségből egyre (el)zártabb gettókban maradt (1. ábra). Mindeközben az alacsony áron megszerezhető házak vonzóvá válnak azok számára, akik a rangosabb városrészekben nem tudtak önkormányzati bérlakáshoz jutni, vagy piaci áron lakást vásárolni, így beköltözésükkel még inkább erősítik az etnikai és szegénységi gettósodás folyamatát. Térbeli, társadalmi, etnikai, kulturális és vagyoni hátrányoknak olyan zárt kombinációja jön létre, amely végérvényesen ellehetetleníti a kitörés, a társadalmi mobilitás további esélyeit. Ezeken a településeken az országos demográfiai és társadalmi tendenciáktól homlokegyenest eltéró folyamatok zajlanak (pl. mérsékelt fejlődést mutató harmadik világbeli országokat jellemző fiatalos korszerkezet, magas analfabetizmus, egészségben eltöltött évek alacsony száma, magas a társadalmi anómia szintje), így fenntartva több párhuzamos társadalmi valóságot.

Társadalmi megrázkódtatások idején általánosságban az alsó (alsóközép) társadalmi státuszúak viselik a transzformáció legsúlyosabb terheit, ők azok, akik nem csupán társadalmi süllyedést, hanem talajvesztést is elszenvednek (LosonCZI Á. 2005). A '90-es évek eleji politikai változások, majd a 2008 után eszkalálódott globális gazdasági-pénzügyi válság nagyban hozzájárult az említett társadalmi réteg lecsúszásához, ezzel együtt a társadalmi és térbeli szegregáció fokának erősödéséhez. Előbb említett underclasst olyan 


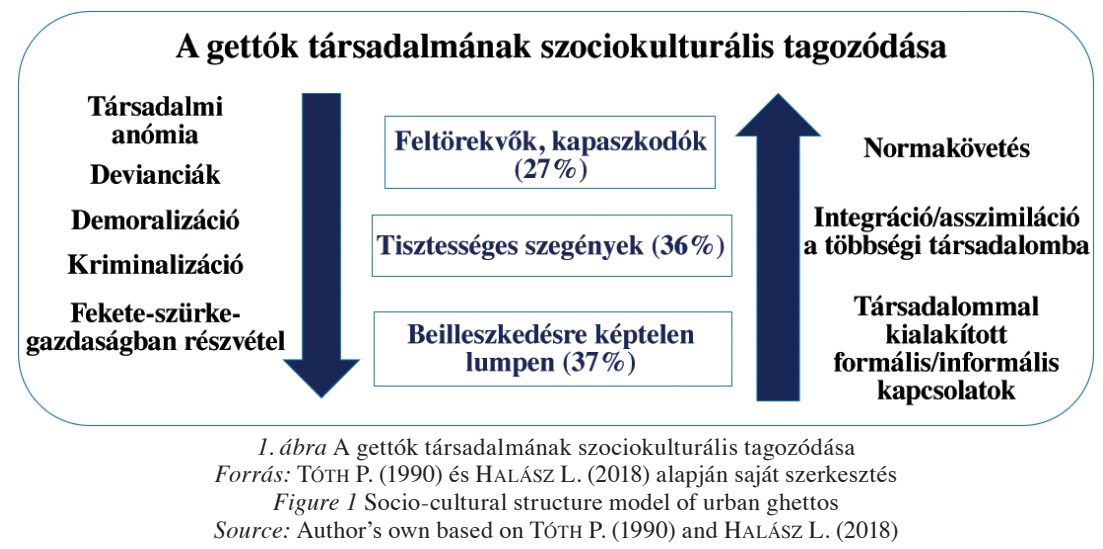

csoportok alkotják, akik bizonyos társadalmi és gazdasági változások következtében „feleslegessé” váltak a munkamegosztás kialakuló (új)kapitalista rendszerében. A posztszocialista térségben kataklizmaszerú változásnak az állami nagyipar szinte korlátlan képesítés nélküli munkaerő-szükségletének megszúnése tekinthető. Súlyosbító tényező, hogy a szocializmus során vajmi kevés foglalkoztatáspolitikai lépés történt a munkaeró átés/vagy továbbképzésére. E mögött az iparfejlesztések és a kedvező lobbihelyzetbe vetett vakhit állt. Ez a társadalmi alsóréteg (kiilleszkedettek) a rendszerváltozás nagy vesztese: marginalizációjuk visszafordíthatatlan, amely nem csak őket, hanem az elkövetkezó két-három generációt is érinti, így átörökített társadalmon kívüli helyzetük évtizedekre bebetonozódott (LADÁNYI J.-SZELÉNYI I. 2014; KovÁcH I. 2012). Ók azok az emberek, akik a posztszocialista átmenet során munkájukat elvesztették és idejekorán kikerültek a foglalkoztatás- és szociálpolitika ellátotti köréből. Rendszeres jövedelem és megfelelő kapcsolati tő́ke hiányában a kitörésre is kevés esélyük adatott. Gyakran többlépcsós zuhanás következett be társadalmi pozícióikban, amit a hányattatások nagyságrendje és hosszúsága jelzett. Számos társadalomkritika bizonyítja (vö. KEMÉNY I. 1972; ANDORKA R.-SPÉDER Zs. 1994; SzIRMAI V. 2019), hogy a politikai változások szociális költségei leginkább az említett szegényeket és elszegényedôket sújtották.

A posztszocialista időszakot jellemző szegénység és nyomor döntően két társadalmi csoportot érintett. (1) 1989 előtt is a társadalmi státuszlétra alján tengődő csoportokat, akik depriváltsága, az anómia szintje miatt kirekesztettnek, kiilleszkedettnek számított. A szocializmus során folytatott önkárosító,énhatékonyságot nélkülöző életmódjuk miatt az 1990-es évek elején elsősorban ők kerülttek a munkanélküliség és a lecsúszás csapdájába. Közéjük sorolhatók az első sikertelen kényszervállalkozók, az elszegényedő kisnyugdíjasok és a nyomorúságos helyzetbe önhibájukon kívül került gyermekek (SPÉDER Zs. 2002). (2) A szegények másik csoportja az államszocializmus során főként a társadalom alsó és alsóközép csoportjába tartozott. Munkahellyel és „kisegzisztenciával” rendelkeztek, azonban szaktudásuk, képzettségük az új gazdasági körülmények között elavultnak, használhatatlannak minősült, így már az 1990-es évtized elején, majd a 2008-as világválság utáni időszakban az állástalansággal és társadalmi státuszvesztéssel, egyértelmú térbeli szegregációval (legyen szó gettósodó aprófalvas térségekről vagy városi gettók ról) kellett szembenézniük (LóRÁNT K. 2017). Ók azok, akik közül sokan kényszerből elhagyták városi lakásaikat és visszamentek vidékre, kisfalvakba, vagy a városok szegénytelepeire, külterületeire költöztek. Oda, ahol a nyomor koncentrálódott, ezáltal a társadalmi mobilitás számukra lezárult (Csite A. - KovácH I. 2000; HALÁsz L. 2016). Megélhetési bázisuk 
megrendülése miatt megfontolás nélkül vettek fel hitelt (gyakran uzsorahitelt), majd hitelcsapdába kerülve anyagilag és egzisztenciálisan a helyi társadalmak legaljára süllyedtek, gyakran hajléktalanokká váltak. A privatizációba, kárpótlásba, a helyi vagyon újraelosztásába, mint eleve vesztesen indulók a kevesebbnél is kevesebbhez jutottak.

\section{Gettók és gettósodó városrészek}

\section{Gettók, gettófelszámolások, társadalmi kirekesztés Miskolcon}

A 20. század első felében a Zsolcai kapu és a Sajó között elhelyezkedő egykori katonai telephely (Szondi telep) vált Miskolc legnagyobb kiterjedésű szegénytelepévé, ahová a város és környékének legszegényebb családjait költöztették. A hetvenes évekig cigányok kis számban éltek a területen, azonban az 1974-es Sajón levonuló árvíz miatt elpusztult Csorbatelep, majd egy évtizeddel később, a jelenlegi Vörösmarty utcai lakótelep helyén egykoron elterülő Gordon városrész nagyszámú cigány lakosságát kényszermegoldás gyanánt elsősorban a gyors ütemben slumosodó, komfort nélküli házakba, kalyibákba költöztették (LENGYEL G. 2009). A városszéli nyomornegyeden kívül városszerte több elértéktelenedett helyet választottak ki az elszegényedett családok számára, újabb gettósodó szegregátumokat létrehozva a főutcán, a Szentpéteri kapuhoz közeli Álmos-udvarban és a Diósgyőr és Miskolc határán lévő Békeszálló (negyvenes években épült munkáskolónia) területén (2.ábra) (TóTH P. 1990).

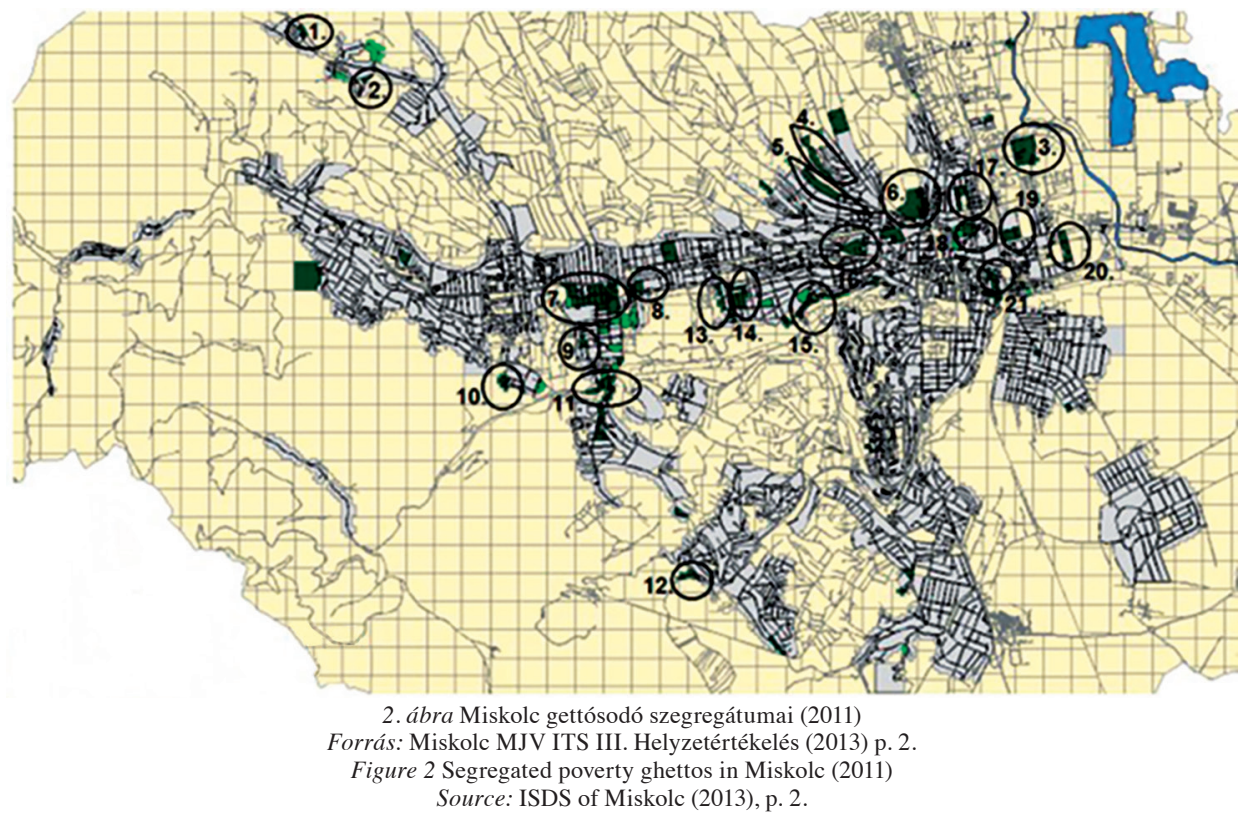

A szocialista iparosítás következtében munkások tízezrei költöztek Miskolcra, akik számára lakótelepeket (köztük az Avast) emeltek. A házak egy részét egykoron szegények és cigányok által lakott területen építették, akik tömegesen kényszerültek városon belüli helyváltoztatásra. Mivel ekkortájt a politikai figyelem az új, csoportos lakásépítésekre irányult, az egyedi építkezéseket és a történelmi jelentôségú városrészek gondozását, 
fejlesztését elhanyagolták, így különösen a belső városrészek slumosodása gyorsult fel. Elkezdődött a legszegényebb, fóként cigány családok beköltöztetése a főutca százéves polgárházaiba, létrehozva a belvárost évtizedekre megbélyegző etnikai gettókat, állandósítva a díszes homlokzatú paloták falai közé zárt szegénységet. A szocializmusban elhanyagolt épületek lakásai évtizedekig szociális bérlakásokként funkcionáltak, a Miskolcra bevándorló, belső és külső migrációban részt vevő, enyhén deprivált cigányok számára tranzitként szolgáltak, emiatt dinamikusan változott mikrotársadalmuk. A lakásokra zsúfoltság, elhanyagoltság, a nagy családokra pedig dezorganizáltság, számtalan belső konfliktus volt jellemző (Dobrossy I. 1993; LENGYEL G. 2009). Aztán a főutca gyors és látványos slumosodását látva már a nyolcvanas években megkezdődött az ottani dezintegratív lakosság kiköltöztetése. A belvároson kívül viszont a szocialista korszak utolsó évtizedében is tovább folytatódott a cigány és szegény családok ide-oda „tologatása”, sokak ideiglenes lakhelyévé váltak a Számozott utcák, a vasgyári telep és a hejócsabai mészüzem melletti, a Pereces, valamint Miskolctapolca-Kőbánya kiürülő bányászkolóniái.

Megindult a lakosság szelektív elvándorlása, a betelepítések következtében az „őslakos” nem cigány népesség néhány év alatt elhagyta az erőteljesen gettósodó szegregátumokat, így a kilencvenes évek elejére mind a város belterületén, mind a periférián alakultak ki több százfös etnikailag és szociálisan homogén gettók. A politikai fordulatot követő gyárbezárásoknak köszönhetően tömegek váltak munkanélkülivé, kerültek kilátástalanságba és nagy hányaduk a meglévő cigány- és szegénytelepekre kényszerült, súlyosbítva a gettók társadalmi problémahalmazát, azok szimbolikus elkülönülését. A duzzadó népességú telepek felszámolásáról már 1992-ben döntött a képviselőtestület, azonban az új évezredig kellett várni a szanálás foganatosításával (LENGYEL G. 2009). A 2000-es évek elején először az Álmos-udvart, majd a Békeszálló nagy részét számolták föl, mégis látványos felháborodást a Szondi telepi putrik szanálása kísérte. A mélyszegénységben élő, döntôen cigány családok többsége ekkor került a város újabb szegény szegregátumába, a Számozott utcákba és a város külterületén lévő barnamezős területre, Lyukóvölgybe és Lyukóbányába, néhányan pedig az Avas lakótelepre költöztek.

A Miskolcon negyed évszázad alatt foganatosított társadalmi válságkezelési gyakorlatok eklatáns példája a gettók felszámolása, majd az ott élők relokalizációja. Az anti- és deszegregációs beavatkozásokat főként házak, tömbök, teljes szegénytelepek, nyomortelepek bontása (kemény típusú városrehabilitáció), az ott lakók folyamatos átköltöztetése, kitelepítése jellemezte. A végleges várospolitikai beavatkozásoknak köszönhetően az utóbbi tíz év alatt hárommal (16-ról 13-ra) csökkent a KSH által szegregátummá nyilvánított téregységek száma. A 2011. évi népszámlálás adatai alapján, az állandó népességet vizsgálva Miskolc belterületén 2470 fó, külterületén 2481 fó élt gettókban, tehát a város népességének 3\%-a (ITS - MisKolC, 2014). Ez az arány azonban valótlan képet sejtet, ugyanis becslések szerint csaknem kétszer-háromszor ennyi, tehát 10-13000fős az említett szegregátumok lakónépessége, akik életvitel-szerúen használják ezeket az urbánus tereket. A város belterületén egy kivétellel a 300 főnél népesebb gettók eltűntek. A 2010-es évtized végén az egykoron hírhedt Szondi telepen 258-an, Tetemváron 225-en, Vikend telepen, az Álmos és Gizella utcában, Bábonyibércen és Békeszállón szegregátumonként 100-150 elsősorban cigány és (mély)szegény lakos él. Tehát a felszínen megoldottnak tünnek a térbeli és társadalmi gondok. Azonban a mélyben a konfliktusok tovább gerjesztődnek, ugyanis a slumosodás, a társadalmi marginalizáció egyre súlyosabb problémahalmazát tapasztaljuk két városrészben, a Számozott utcákban és Lyukóban.

A Diósgyőri Stadion környékén található ún. Számozott utcák házai több mint száz éve épültek a gyári dolgozók számára. A dezindusztrializáció következtében a munkások nagy számban költöztek el területrôl, a lelakott, rossz állapotú ingatlanok pedig üressé váltak. 
Ezek kereslet híján a Miskolci Ingatlangazdálkozó Zrt. kezelésébe kerültek, amely a többnyire komfort nélküli lakásokat bérbe adta döntően mélyszegénységben élő cigány családoknak. Megközelítőleg 20 éven keresztül ez a városrész jelentette a Miskolc belterületén élő fizetésképtelenné, a lakóközösséggel összeférhetetlenné váló, vagy tranzitállomást a városrehabilitációs projektek miatt felújított épületekből kiköltöztetett családok százai számára. Csakhogy 2014-ben a helyzet megváltozott, a többségi társadalom felől tapasztalható fokozódó elégedetlenség (amely a telepfelszámolást támogató aláírásgyuujtésbe torkollott) miatt a városvezetés a telep ,leradírozása” mellett döntött. Önkormányzati rendelet értelmében azon családok, akiknek nem volt tartozása és érvényes bérleti szerződéssel rendelkeztek, 1,5-2 millió forintos kártérítést kaphattak, ha Miskolc határain kívülre költöztek (a problémaexport tankönyvi példája!), viszont a megvásárolt lakások adásvétele öt évig jogilag kivitelezhetetlenné vált. Jelenleg nagyjából 300-350 család lakja a Számozott utcák házait, akik kisebb része tulajdonos, többsége határozott vagy határozatlan idejú bérleti szerződés alapján él ott, míg egyesek illegális lakásfoglalók. Ezen kusza tulajdonviszonyok miatt is bonyodalmas az egyenlő bánásmód biztosítása a kiköltöztetéskor, majd az azt követő relokalizációkor. Ezzel kapcsolatban legégetôbb feladat a létminimum alatt élő lakosok újbóli letelepítése, amely háromféleképpen történt/történik. (1) A város külterületéhez tartozó Lyukóvölgy és Lyukóbánya több ezres népességú infrastruktúra-hiányos gettójába költöznek, (2) olcsó ingatlanvásárlási lehetőséget nyújtó gettósodó aprófalvakban találnak lakóhelyet, ahonnan a kitörés esélytelen, vagy (3) hajléktalanná válnak.

Az ország jelenleg legnépesebb szegregált gettója a Miskolc külterületén lévó Lyukóbánya és Lyukóvölgy, méghozzá az egykori bánya bejáratához közeli hat km hosszú völgyben sorjázó zártkertek zónája (1. kép). Itt a KSH hivatalos adatai alapján 2500-an, míg becslések szerint 6-8000 fô lakik életvitel-szerúen. Ezen a területen, a szocializmus idején tel-

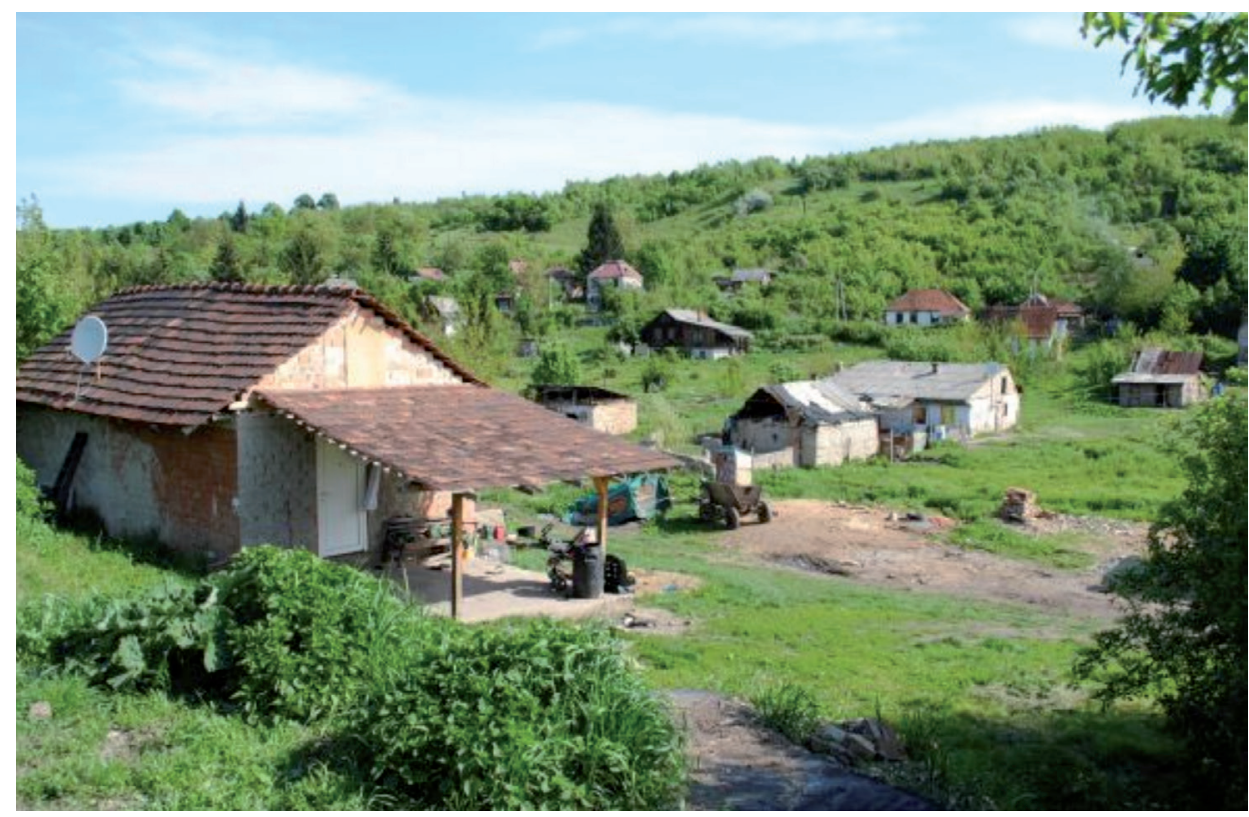

1. kép Miskolc jelenlegi legnépesebb gettósodott szegregátuma: Lyukóvölgy

Photo 1 Lyukóvölgy: The most populous segregated poverty ghetto of Miskolc

Forrás/Source: https://magyarnarancs.hu/kismagyarorszag/normalis-ember-ilyen-uzletbe-nem-megy-bele -elutasitjak-a-nyomortelepeken-elok-miskolc-millioit-89983 
keket parcelláztak az egykori Lenin Kohászati Múvek munkatársai és bányászok számára, hétvégi pihenőhely gyanánt (víkend ház, kiskert), valamint sok idős miskolci is kiköltözött ide. A szegények kivándorlása Lyukóba az 1990-es években kezdődött, de a folyamatot felgyorsította a belvárosi putrik, a Szondi telep és a Békeszálló felszámolása, valamint Miskolc gettósodó utcáinak, blokkjainak szociális városrehabilitáció miatti bontása vagy felújítása. A ,városrészben” nincs bolt, iskola, orvos, utcanevek és a közmúvesítés is hiányos. Elsősorban azok választják lakhelyül az etnikailag és szociálisan homogenizálódott területet, akik kényszerúségből feladták városi lakásaikat: magas költségek, eladósodás, bontás miatt, esetleg olcsóbb körülmények közé szándékoztak költözni. A magántulajdonú lakásokért, a lebontott házak megváltásáért kapott összeg elegendőnek mutatkozott ahhoz, hogy a rászorultak itteni telkeket vásároljanak, ahová alacsony komfortfokozatú kis házakat építenek, a meglévő víkend házakat átalakítják, szélsőséges esetekben ideiglenes sátrakban húzzák meg magukat. Megtalálhatók itt kilakoltatottak, önszántukból menekülők, faluról városba költöző szegények és hajléktalanok. Megjegyzendő, a lyukói jelenség nem Borsod-specifikus, ugyanis az elmúlt évtizedben a külterületi, tanyás vagy zártkertes térségek egy része krízisövezetté alakult. A városhoz közel jelenleg ezeken a helyeken lehet legolcsóbban ingatlanhoz jutni, a legszegényebbek néhány tíz- vagy százezer forintért vehetnek - illetve ingyen foglalhatnak - házat, fészert vagy szerszámoskamrát (vö. BERKI M. 2016; HALÁsZ L. 2016).

A több ezer fôs, félig-meddig illegálisan betelepült gettó társadalmi képe sokveretü. Együtt élnek a „tisztes” szegények, a nyugdíjasok, a kitörni kívánó cigánycsaládok, velük párhuzamosan a társadalom underclass rétegéhez tartozó, integrálódni és etikai normákat követni nem hajlandó, illegális jövedelmekből (pl. uzsora, a modern kori rabszolgatartás formái, mint a csicskáztatás vagy prostitúció, illetve drogterjesztés) magukat fenntartó, a telepet rejtőzködés céljából választó búnözői csoportok is. A telep krónikus probléma. A város belterületétől távol, a helyi társadalommal mindennemú interakciót mérséklő fizikai, szimbolikus és mentális határokkal elzárt gettó a nyomor, az etnikai és szociális szegregáció melegágya. A társadalmi, szociális, etnikai, közbiztonsági probléma a miskolci belterületeken élők számára megoldottnak tűnik, azonban a NIMBY (Not In My Back Yard) effektus következtében eltérő térbeli struktúrában, súlyosabb konfliktusokat generálva tovább bontja a térségi társadalom szövetét.

A miskolci panelházakba „zárt” gettók megjelenése (és eltűnése) szintén releváns elemzési tartalmat jelent az elmúlt néhány évtized társadalmi változásainak szemszögéből. A Pécsett található uránvárosi után az ország második legnépesebb vidéki lakótelepe, az Avas a panelekbe zárt szegregáció, gettóképzódés egyik szimbólumává vált (EGEDY T. 2000). Hogy miért? A lakótelepet 1973 és 1985 között, három ütemben építették a Miskolc belvárosa fölé magasodó Avas hegyen, lakásaiba elsősorban alacsony és közepes státuszba tartozók költöztek. A rendszerváltozást követően a miskolci munkalehetôségek szúkülésével, életfeltételeik romlásával a várost nagy számban elhagyó egykori lakók ingatlanjai - ugyanígy a Vörösmarty úti és a diósgyőri Árpád úti lakótelepek üres lakásai - kereslet híján üresen maradtak. Ezeket a még magántulajdonban lévő lakásokat kezdték 2005-től a Fészekrakó Program keretében főként vidékről érkező, 35 év alatti többgyermekes családok számára kedvezô áron eladni. A program jelentős állami támogatást és kedvezményes hitelkonstrukciókat biztosított az újonnan beköltözők számára. A kedvező helyzetet kihasználva népes bűnügyi csoport szerveződött, akik összehangoltan, együttmúködve és rendszeres haszonszerzésre törekedve megkezdték üzérkedéseiket: Az elkövetők vidékre utaztak, ahol kimondottan hátrányos helyzetú, alacsonyan kvalifikált cigány családoknak ajánlották fel a jobb élet lehetőségét, komfortos környezetben. A csalárd üzletkötéseknek köszönhetően több mint 100 ingatlan került olyan családok tulajdonába, akik hitel- és 
rezsitörlesztésre kezdettől fogva képtelenek voltak, sôt az önrészt a gyermekek után járó szociálpolitikai támogatás - mint gyakran egyetlen rendszeres bevételi forrás - összegéből fizették. A csalásra 2009-ben derült fény és 2012 és 2015 között folytatták le a pereket. A lakótelepre beköltöztetett több száz cigány családot társadalmilag hármas tagoltság jellemezte (vö. 1. ábra): Harmaduk integrációban legelöl tart, gyermekeiket oktatási intézménybe járatják, a szülők állandó bejelentett munkahellyel rendelkeznek, lakókörnyezetük rendezett. Harmaduk enyhén deprivált sokgyermekes család, a nyomortól távol élnek. Harmaduk az ún. lakáspusztító lumpenek, dezintegratív emberek, akik a lakótelepi együttélés kívánatos normáit nem képesek vagy nem tudják követni, azonban nem tekinthetők búnözői csoportoknak (TóTH P. 1990; KEMÉNY I.-JANKY B. 2004; EGEDY T. 2005). Ebből is látszik, hogy a média által felkorbácsolt közhangulat és a lakótelep erőteljes megbélyegzése, súlyos gettóként feltüntetése túlzó. Az újonnan érkezettek között valóban megtalálhatóak rendbontó, búnözó életmódot folytató lakosok, azonban ez nem lehet alapja az általánosításnak. Napjainkban látványos kettősség jellemző az Avason. Nyugodt, rendezett környezetú és slumosodásnak indult, lelakott panelházak váltják egymást. Egy ház közösségét egyetlen lumpen család megmérgezheti, ez az ingatlanok elértéktelenedéséhez, eladhatatlanságához, lakók közötti éles konfliktusokhoz vezethet, így a legjelentősebb károkat ezek az avasi lakóközösségek szenvedik el. Ennek ellenére a lakótelep búnügyi fertőzöttsége átlag alatti, súlyos bűncselekmények (lakásfeltörések, autólopások) száma elenyésző, azonban a szabálysértések (pl. csendháborítások) és a társadalmi együttélés normáinak megszegése állandó probléma. A kilakoltatások megkezdődtek és vontatottan, de haladnak. Társadalmi igazságosság/igazságtalanság kérdését veti fel, hogy felületesen vizsgálják meg, vajon az egykori lakónak miért van tartozása (pl. munkahely elvesztése vagy krónikus betegség miatt), így önhibájukon kívül is lakásuk elhagyására kényszerítenek több tucat avasi lakost. A kiköltöztetés ugyanakkor a gondokat nem orvosolja, hanem - a Számozott utcákban történtekhez hasonlatosan - földrajzilag áthelyezi, a lyukóvölgyi és lyukóbányai nyomortelep, a Taktaköz és Szikszó környéki gettósodó aprófalvak, zsáktelepülések váltak a kilakoltatott családok új (kényszer)lakóhelyeivé. A problémás családok kiköltöztetését lassította egyrészt a Kormány devizahiteleseket védő kilakoltatási moratóriuma, másrészt a Miskolci Önkormányzat által 2009-ben ratifikált együttélési kódex. Ez utóbbi meghatározta az egy lakásban tartózkodó személyek számát, azonban annak betartatását a rendvédelmi szervek képtelenek voltak hatékonyan foganatosítani, ugyanis az ellenőrzések során elküldött, illegálisan ott lakók idő előtt visszaszivárogtak.

Az avasi lakótelep-építés notórius II. üteme során emelt panelházak egy részét és azok környezetét 2013 és 2015 között rehabilitálták, a lakosság szociális gondjait részben kezelték, közösségépítő (pl. városi kertészkedés) és foglalkoztatási programokat valósítottak meg, a közterületek humanizálásához hozzákezdtek.

\section{Szociális válság és válságkezelés Ózdon}

Az alacsonyan kvalifikált, városi életmódhoz nehezen alkalmazkodó vidéki szegényparasztok és cigányok tömegei a 20. század elejétől kezdve érkeztek Ózdra és térségébe (KARVALICS L. 1996), ugyanis a fóként kétkezi szakmunkát igénylö, rohamos tempóban fejlesztett nehézipara ezt megkövetelte. Bevándorlásuk volumene az erőltetett iparosítás és munkaerő-ínség miatt a szocializmusban többszörösére nőtt. Letelepedésük lokalizációját, majd városon belüli migrációjuk irányát két tényező határozta meg. Egyrészt Ózd szerteágazó, poliphoz hasonlító településstruktúrája, amelyet társadalmilag, gazdaságilag, kulturálisan és szimbolikusan is eltérő „településcsápok” alkotnak. Ezek a településtesttől fizikailag elkülönült városrészek a különböző státuszú, etnikai, kulturális, társadalmi cso- 
portok szegregációjának kiváló földrajzi teret/alapot jelentettek. Másodsorban a városi lakóépületek minőségi különbözősége. A 20. századi iparosításhoz kötődő, valamennyi kolóniás szerkezetú lakásépítési trend, stílus megjelent Ózdon a folyamatos és konjunkturális városfejlődésnek köszönhetően. Számos kolóniát (pl. Velence telep, Kisamerika, Tisztisor) tudatosan a gyár vezető mérnökei, valamint a település értelmiségi rétege számára építtettek az adott kor legmodernebb építészeti stílusában, legmagasabb komfortfokozattal (DoBOSY L. 2001). Az évtizedek múlásával egyre jobb minőségű, összkomfortos lakásokat emeltek (utoljára a belvárosi tájképet máig uraló tízemeletes házgyári betonkolosszusokat), ezek viszont közkedvelt lakásoknak bizonyultak, evégett a város közepes és magas státuszú családjai, sốt az újonnan Ózdra érkezők számára is színvonalas új lakóhelyet jelentettek. Az intraurbán térben történő trendszerủ lakóhely-változtatás miatt egyre több egykoron nívós kolónia épülete - felújítás, környezetrendezés híján -értéktelenedett el, majd vált üressé. Az 1970-es évek végétől kezdve kényszerűségből az említett alacsony komfortfokozatú, kis alapterületű házak sokasága került az Önkormányzat (akkor még Tanács) tulajdonába és lettek szociális bérlakások. Ide a városszéli cigánytelepek és szegénytelepek lakóit költöztették be, így váltak a jelenlegi városközponti szegénygettók előfutáraivá. Ózdon a rendszerváltozás keretében történt társadalmi-gazdasági változások, a kilátástalanság, a növekvó arányú és tartós munkanélküliség jelensége az elszegényesedési folyamatot felerösítette, ezzel párhuzamosan a települési demográfiai pálya egyre kedvezőtlenebb jelleget mutatott. Az 1990-es években főként az értelmiség, a kvalifikált munkaeró és a kilátástalanságtól tartó fiatalok hagyták el a várost. A 2000-es évektől kezdve azonban követték őket a szakmunkások (pl. lakatosok, villanyszerelők) és az alsóközéposztály azon tagjai, akiknek sikerült ingó és ingatlan vagyonukat értékesíteni és elmenekülni nem csak a városból, hanem Észak-Magyarországról is, elindítva a negyed évszázada tartó városzsugorodást és súlyosbodó rezidualizációs folyamatot. A közelmúltban a 30 év alatti korosztály tagjai közül csak a kalandvágy tartotta Ózdon a fiatalokat. A munka nélkül maradt, képzetlen cigány lakosság és a halmozottan hátrányos helyzetû́ családok aránya folyamatosan nőtt, egyes városrészekben egyeduralkodóvá vált. Az életkörülmények romlottak, ezáltal slumosodott, alacsony komfortfokozatú vagy komfort nélküli lakásokkal teli etnikai és/vagy szociális gettók alakultak ki (2. kép).

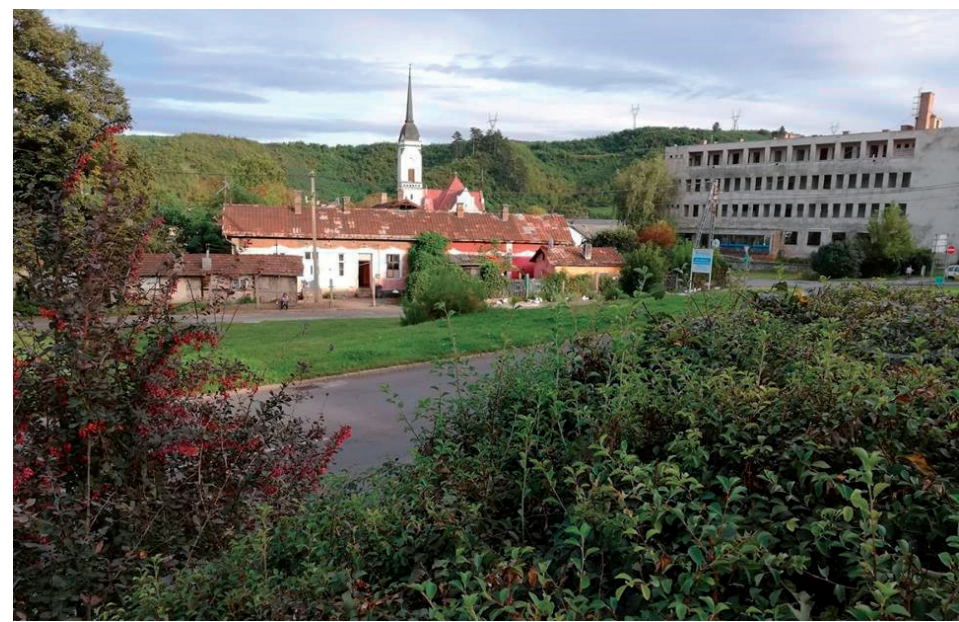

2. kép Ózd-Újtelep gettósodott szegregátuma (Történelmi Ózd egykori faluközpontja) Forrás: Saját felvételek

Photo 2 The historic centre of Ózd recently one of the most expanded urban poverty ghettos (named: Ózd-Újtelep) Source: Author's own 
A krízis súlyosságát bizonyítja, hogy Ózd esetében mai napig releváns probléma - Magyarország-szerte az 1990-es években még gyakori, azóta átalakulóban vagy visszaszorulóban lévő területi-társadalmi jelenség - a városközponti homogén gettók megléte. Ezek a települési egységek a 21. századi vidéki nyomor „vegytiszta” megtestesítői (3. ábra). Kialakulásukhoz vezető folyamatok a térségben már az államszocialista rendszerben elkezdődtek, azonban a posztszocialista időszakban számottevően erősödtek. A középosztályosodás útjára lépett családok az 1990-es évek elejéig úgy költöztek egyre jobb lakásokba, hogy a gettósodó területen belül, ahhoz földrajzilag közel változtatták lakóhelyüket. Ezzel szemben a városi gazdasági válság mélyülését övező, ellehetetlenülő szociális és közbiztonsági helyzet az anyagilag tehetősebb rétegeket a városrész, sőt a térség elhagyására ösztökélte, így tulajdonképpen kizárólagossá vált a legelesettebb cigány és szegény családok koncentrációja. A slumosodás addig fokozódott, míg nem akadt olyan, többé-kevésbé konszolidált körülmények között élő társadalmi csoport, amelyik az elköltözés által támadt űrt betölthette volna (LADÁNYI J. 1991; LADÁNYI J. - VIRÁG T. 2009).

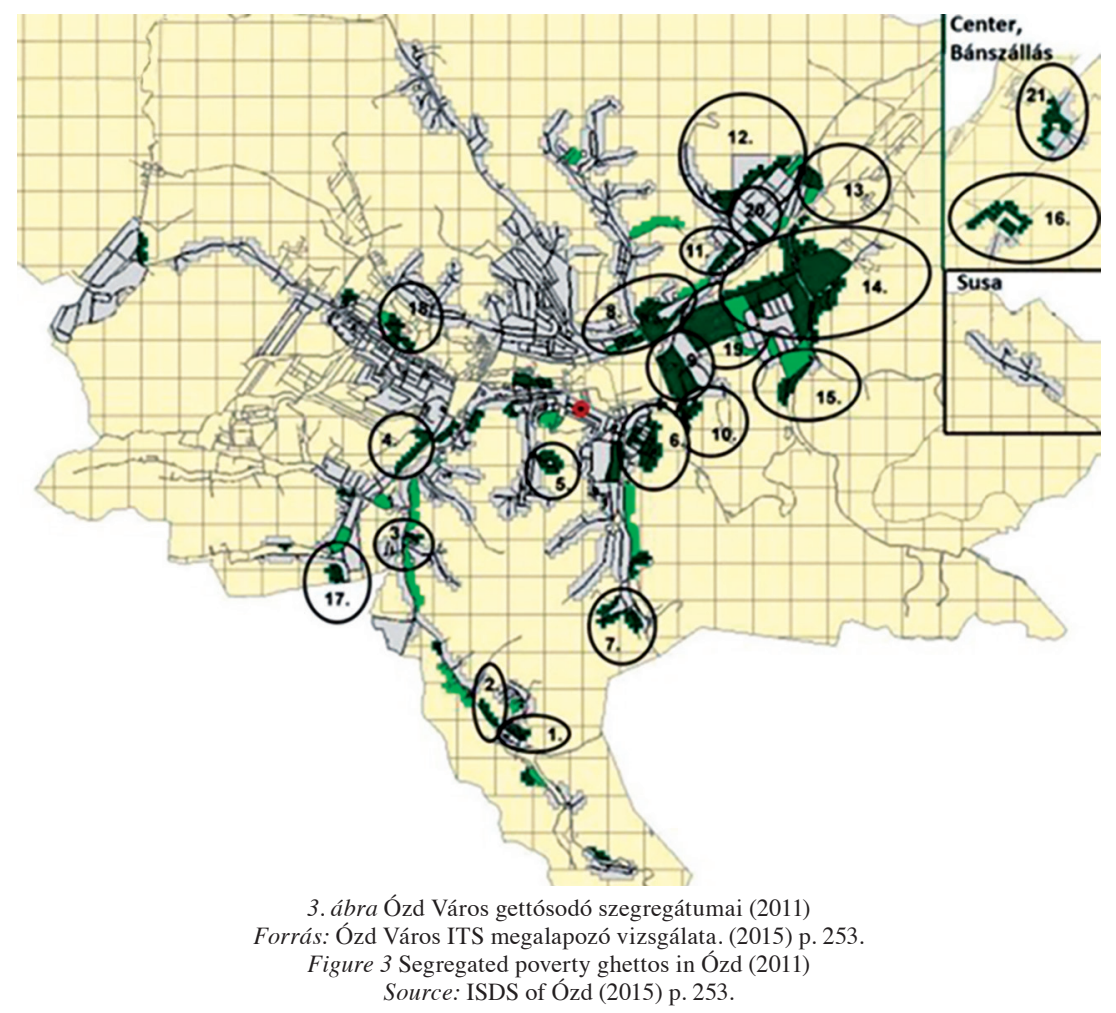

Ózd újkapitalista városfejlődése során is folytatódott a gettósodott szegregátumok kiterjedésének növekedése, sőt újabb városrészek váltak etnikai és szociális értelemben homogén gettókká. Egy évtizede 16, napjainkban 21 gettósodott szegregátum különíthető el a városban (ITS - ÓzD, 2015), ahol a lakosság 20-25\%-a (nagyjából 7-8000 ember) él. Ez, mind a gettók számát, mind népességhez viszonyított arányát tekintve az országban példa nélküli! A legsúlyosabb társadalmi és gazdasági helyzetú gettók városrésznyi kiter- 
jedésúek. Sajóvárkony 1655 lakosával a legnépesebb szegénytelep, az 1120 fós Újtelep a városközponti homogén gettó eklatáns példája. Említést érdemel a közelmúltban a slumosodást lefékező városrehabilitációs beavatkozások hatására javuló társadalmi összetételú, noha így is népes (711 lakosú) Velence telep, továbbá a város külső, falusias övezetében sorjázó gettók. Közülük - a médiaszerepléseknek köszönhetően országos hírnévre szert tett - 638 fős Hétes telep, illetve a nagyjából fél-félezer lakosú Somsály és Tábla (IVS ÓzD, 2008). Krónikus társadalmi probléma a hajléktalanság, akik jelentékeny része illegális lakásfoglalóként a gettók mélyén húzzák meg magukat.

Ózd város nagyjából 1000 darabos önkormányzati lakásállományának közel fele szociális bérlakás, ezek döntő többsége komfort nélküli vagy szükséglakás (gyakorlatilag putrik) és kivétel nélkül a gettósodott területeken találhatóak. 1993-ban még 2600 ingatlan tartozott az Önkormányzat tulajdonába (ebből 800-at privatizáltak), azonban két évtized alatt 800 bérlakást egyszerúen elbontottak. A folyamat 1994-ben kezdődött. Két, darabonként 96 ún. Cs-lakásból (csökkentett komfortfokozatú) álló házba szociálisan rászoruló családokat költöztettek. (A háztömböket tíz év alatt oly mértékben lepusztították, hogy életveszélyességük miatt 2004-ben és 2005-ben a bontás mellett döntöttek annak érdekében, hogy a város legnépesebb lakótelepe, a 10000 lakosú Béke telep rendjét biztosítsák.) A családok kiköltöztetésével viszont több tucat elhanyagolt, gyakran életveszélyes, kiürített ingatlant hagytak sorsára, amelyeket célba vettek illegális házbontó brigádok (3-4 kép). A helyzeten rontott a munkahelyek hiányában Ózdról véglegesen elköltöző családok után üresen maradt ingatlanok nagy száma, ezek kereslet hiányában eladhatatlanná váltak és lebontásukban néhányan pénzt láttak. Elsősorban a nyomorban élők számára biztosítják így a télire való tűzifát, valamint a vashulladék eladásából származó jövedelem helyi viszonyok között elfogadható megélhetést is biztosít (MoLDOVA GY. 2017).
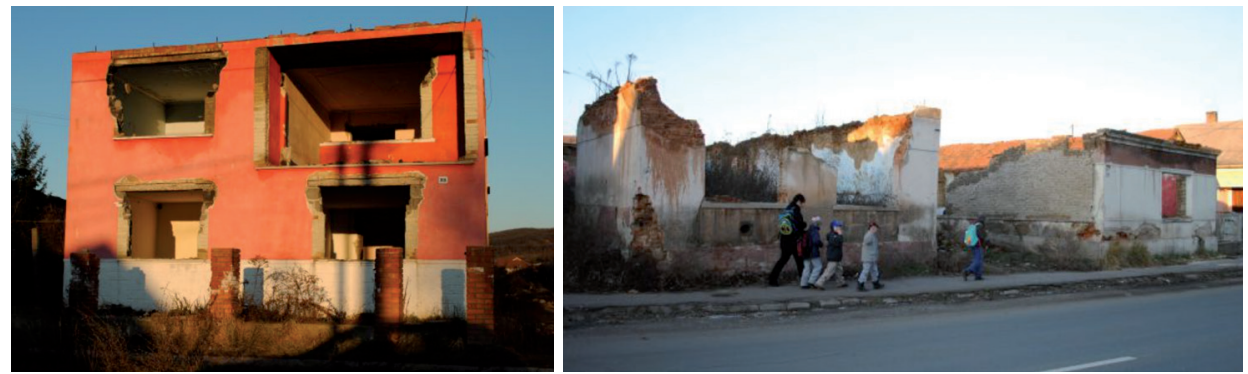

3-4. kép Illegális házbontások Ózdon

Photo 3-4 Illegal house destructions in Ózd

Forrás/Source: Google Maps; https://magyarnarancs.hu/kismagyarorszag/ozdi-romhazak-szazaval-lopjak-oket-84183

Évente 30-40 ház, „tünik el” a városból, az elmúlt másfél évtized során közel 1000 lakásnak maradt húlt helye. A romos házak nagy részét jelzálog is terheli, így eladhatatlanok. Ezek is a házbontó-brigádok áldozatai lettek. A helyzet olyannyira kilátástalanná vált az új évezred elejére, hogy a várost elhagyó lakók nem ritkán ingyen ajánlották fel lakásaikat az Önkormányzatnak, hogy azokat rehabilitációs keretükből bontsák el. Sơt, helyi vállalkozók rendszeresen fizetik ki a jelzálog összegét annak érdekében, hogy az immáron tehermentesített házakat ingyen az Önkormányzatnak átadják szanálásra. Legsúlyosabb helyzet az eddigi szociális városrehabilitációs beavatkozásokból kimaradt gettósodott negyedekre (Bánszállás, ahol a szociális bérlakások 60\%-át elbontották, Sajóvárkony, Hétes - itt 120 házból 53 maradt, Somsály) jellemző. Igaz, az elbontott házak nagy száma figyelemreméltó, azonban az ingatlanpiac jövőjét még inkább beárnyé- 
kolja a megsemmisítésre váró, félig eldózerolt, néhány falcsonkból álló, vagy teljes egészében elbontott/elhordott ingatlanok látványa. Városszerte számos gettósodást egyelőre elkerülő vagy alacsony fokon gettósodott településrész található (pl. Center, Susa, Uraj), azonban itt is gyors lakosságcsere zajlik, az alacsony státuszú lakosok aránya nô, így az elmúlt évtized anti- és deszegregációs politikájának fő feladata a már létezó gettók helyzetének javítása mellett a szegregáció újratermelődésének, illetőleg súlyosbodásának megakadályozása.

Amint az előzőekben olvasható, egyes városrészek slumosodása már a nyolcvanas években elindult, majd a városi ipar leépülése, a kilátástalan helyzetbe került csoportok aránynövekedése katalizálta a folyamatot. A konfliktusok mérséklése érdekében a kilencvenes éveket és az új évezred elejét tűzoltás-jellegú, látványos eredményt mellőző beavatkozások jellemezték, hosszú távú javulás nélkül. Azonban a 2000-es évek második felétől a válságkezelés fontos pillérének számító városrész-megújítási programok megkezdődtek azzal a céllal, hogy oldják az etnikai gettók homogén társadalmi struktúráját, rehabilitálják az épületállományt, revitalizálják a környezetet, javítsák az életszínvonalat, növeljék az ott élők társadalmi mobilitásának esélyeit. Hangsúlyozandó, hogy Ózdon, a Miskolcot néhány éve jellemző antiszegregációs beavatkozások (a „kemény” városrehabilitáció szellemében leromlott lakásállomány szanálása és az ott élők tömeges ki- és átköltöztetése) nem lehet sem cél, sem alternatíva.

2011-ben, majd 2013 és 2014 között két, közel 100\%-ban halmozottan hátrányos helyzetben élők által lakott egykori kolónián, a Velence és Hétes telepen hajtottak végre $s z o$ ciális városrehabilitációt (5. kép). A komplex program keretében a Velence telep 48 kétszintes, 1920-as években épült, jelenleg örökségvédelem alatt álló házai közül először négy és fél szociális bérlakást állítottak helyre, illetve közösségi házat is kialakítottak. A rehabilitáció sikeresnek bizonyult, így újabb önkormányzati tulajdonában lévő öt és fél darab kétszintes, többségében az alapszerkezetig elbontott, életveszélyes társasházat újítottak fel. Ezekben összesen 36 összkomfortos lakást alakítottak ki, illetve a közösségi házat fejlesztették, valamint közbiztonsági pontot hoztak létre. A rehabilitált épületekbe integrált környezetből költöztettek be (ismét) a társadalmi együttélés normáit és szabályrendszerét elfogadó ózdi lakókat. A beköltöztetés első ütemében főként fiatal házaspárok érkeztek a telepre, akik állandó munkahellyel rendelkeztek, noha panellakásaik fenntartása és a rezsi fizetése számukra nehézséget okozott. A második ütemben - a képviselőtestület döntésének értelmében - lényegesen szigorúbb követelményeknek kellett megfelelnie az itt letelepedni vágyóknak. Munkaigazolás mellett kötelező egyéni költségtervet készíteni, amely a rossz anyagi körülmények közötti családok számára egyelőre megoldhatatlan.
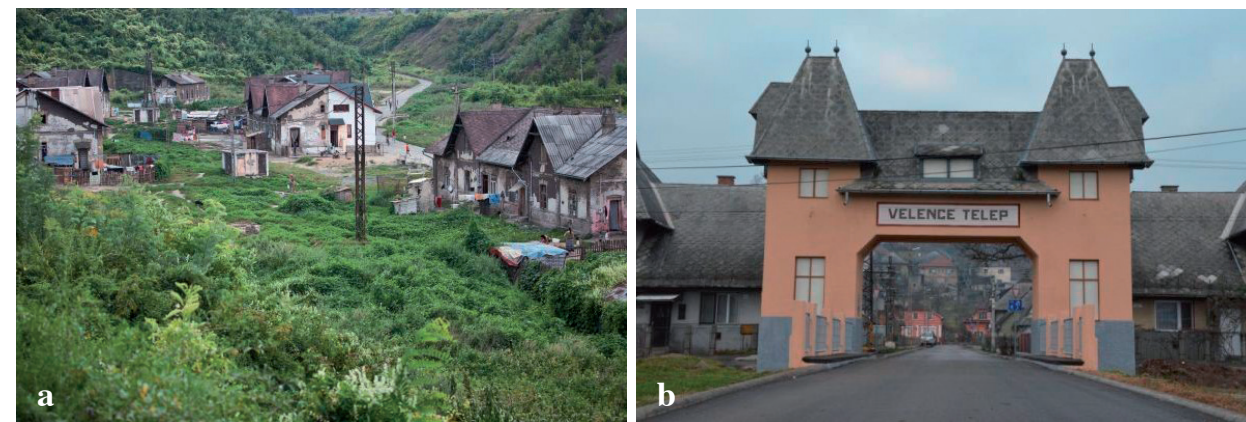

5. kép Ózd városrehabilitáción átesett telepei: Hétes (a) és Velence (b)

Photo 5 Neighbourhoods after urban rehabilitations: Hétes Community (left) and Velence Community (right) Forrás/Source: archivum.sajto-foto.hu (a); http://www.boon.hu/megmentettek-a-tortenelmi-koloniat-ozdon/2969451 (b) 
Velence telep kivételes helyzetét annak köszönheti, hogy társadalmilag és az épületek állagát tekintve a negyed még menthetoonek tűnt más, hasonlóan értékes épületekből álló szegregátumokkal szemben.

Hétes századelőn épített kolóniáját a gyárvezetôknek szánták. A város legjobb módú negyedeként ismerték, mára viszont a nyomor uralja, a város reménytelen gettójává vált. Az etnikailag homogén telepen kisebb léptékú szociális városrehabilitációs beavatkozásokat foganatosítottak. A házak egy részébe kártyás villanyórákat helyeztek, a kerteket felújították, fürdőházat alakítottak ki. Ennek ellenére a Velence telepi eredményekkel ellentétben az életminőségen a program nem tudott változtatni, az áramlopások folytatódtak, a fürdőház vizesblokkjait szétverték, a kialakított közösségi kertek a gondozatlanság szimbólumaivá váltak. Kerítés, udvar, kert sehol nincs. A házak többsége komfort nélküli, a családok közkutakról hordják a vizet, amelyekre szúkítóket kellett helyezni a pazarló vízfogyasztás miatt. A két telepen végrehajtott rehabilitáció eredményei szöges ellentétben állnak egymással. A központi elhelyezkedésú Velencén a helyzet normalizálódott, a társadalom heterogenizálódása lassan, de biztosan elindult, a gettósodást sikerült mérsékelni. A város szélén lévő, fizikailag és szimbolikusan is zsákutcás Hétesen a beavatkozásokat kudarc követte, a társadalmi és gazdasági helyzet változatlanul problematikus, az etnikailag homogén gettó leszakadása megállíthatatlan.

\section{Összefoglalás}

Terület- és településfejlesztési beavatkozások sokasága ellenére a szociális és/vagy etnikai szegregáció látványos terei, a gettók évtizedek óta részét képezik Észak-Magyarország társadalmi valóságának. Ennek hátterében a posztszocialista kelet- és közép-európai térséget jellemző, ám globálisan is érvényre jutó fontos tendenciák bújnak meg. (1) Az alsó középrétegek jelentős részének lecsúszása, emellett a mélyszegénység, mint tartós életforma fennmaradása és elterjedése. (2) Növekednek a településen belüli különbségek, a kedvezôtlen adottságú térségek leszakadnak, ezeken a területeken belül újabb gettósodó szegregátumok alakulnak ki, valamint a régiek is fennmaradnak, deklasszálódnak. Ehhez a folyamathoz nagyban hozzájárulnak a gazdasági válságok (pl. '90-es évek eleje, 2008 utáni fél évtized) társadalmat megroppantó hatásai. (3) A többségi társadalom és a cigányok közötti konfliktusok halmozódása és megoldatlansága, amely elősegíti a magas és alacsony státuszcsoportok közötti fizikai, mentális és szimbolikus elkülönülés fennmaradását. Társadalmi, gazdasági, természeti, politikai és kulturális tényezők egymással összefonódva, egymást erősítve okozták és okozzák azt a komplex válságot, amely fenntartja mind a városokban, mind a vidéki terekben található gettók létezését.

A gettók kialakulása egy folyamat végállomása. Először a válságba került települések, településrészek lakossága differenciálódik, megkezdődik eleinte a magasabb, majd a közepes, végül az alacsony státuszúak szelektív elvándorlása, végül a társadalom alján elhelyezkedő, vagy onnan kiilleszkedett (underclass) réteg tagjai maradnak - pontosabban bent ragadnak. Kialakulnak a koncentrált szegénység terei, amelyek gyakran a magas státuszúak elit városrészei közvetlen közelében helyezkednek el. Fennmaradnak szélsőségesen polarizált társadalmú „,kettős városok”, a későkapitalista városfejlődés mintapéldái. A legszegényebbek számára a társadalmi mobilitási csatornák bedugultak. Az ingatlanállomány pusztulása fokozódik, társadalomszervezési zavarok erősödnek és állandósulnak, a társadalmi és gazdasági konfliktusok halmozódnak, létrejönnek a nyomor szigetei - harmadik világbeli, posztgyarmati státuszú országokban tapasztalható demográfiai és társadalmi jellemzőkkel. A szegénység látványos tereiben keletkező problémák mérséklését gyak- 
ran ún. kemény típusú városrehabilitációval, tehát a telepek végérvényes felszámolásával igyekeznek megvalósítani. Ezek eredményessége a település földrajzi elhelyezkedésétől, a negatív előjelú társadalmi folyamatok súlyosságától, a gazdaságszerkezet minőségétől, a válságelemek meglététől, az országos szociálpolitika eszközrendszerének hatékonyságától, a településvezetés rátermettségétôl és nem utolsósorban a többségi társadalomhoz tartozók, illetôleg gettókban élők közötti életmódbeli és mentális távolságtól függ.

A gettók vagy gettósodó településrészek a többségi társadalom számára „feleslegessé” váló ún. hely nélküli terekké válnak, amelyek nem biztosítják a magasabb társadalmi státuszúak számára a megfelelő életforma kialakításának lehetőségét. A tény, hogy az alacsony társadalmi státuszú, döntően cigány és (mély)szegény családok ebbe a térbe szorultak, plasztikusan mutatja mind a társadalom elkülönítési törekvéseit, mind a halmozottan hátrányos helyzetú családok társadalomban elfoglalt, pontosabban társadalomból kitaszított pozícióját. A helyi önkormányzatok igen hathatósan közremúködtek abban, hogy az etnikai gettók kiterjedése zsugorodjon, homogenitása mérséklődjön az elmúlt évtizedekben.Ezt azonban de- és antiszegregációs célzatú városrehabilitációs projektekkel érték el, amelyek végérvényes bontásokkal és a nem kívánatos területeken élő szegények és/vagy cigányok jelentős részének kiszorításával jártak. A felszínen megjelenő látványos eredményeket beárnyékolja a tudat, miszerint az etnikai alapú gettósodás mértéke nem csökkent számottevően a térségben. Ehelyett a gettósodás mintázata változott meg, tehát a lakóhelyi szegregáció fennmaradt, csak módosult formában. A kiterjedt, városközponthoz közel elhelyezkedő gettók egy része eltűnt, a városokból folyamatosan seperték (és seprik) ki a szegénységet. Helyüket a térben fragmentált, nagyobb számú, etnikailag hasonlóképpen homogén negyedek vették át. Tovább fokozódott a legszegényebb családok koncentrációja a város szélén elhelyezkedó szegénytelepeken, a külterületi lakhatás céljára alkalmatlan ,ingatlanokban”, valamint a gyors ütemben gettósodó térségbeli aprófalvakban, zsákfalvakban. Sőt, a térségben - az országos folyamatokkal megegyezóen - megjelent és népesedik a szegényeknél is szerencsétlenebb, jövönélküli, nyomorban élók csoportja. Kettejük közötti fó különbség, hogy a szegény emberben még él a remény sorsa jobbra fordulását illetôen, képes is tenni érte, létezik kitűzött célja, így a szegénységből vissza lehet kapaszkodni. A nyomor ezzel szemben megroppantja a családi/települési közösségeket és generációról generációra öröklődik. Ha a gettókban az ott élők többsége nincstelen, képtelenek lesznek önerôből kilábalni a nyomorból. Az etnikai és társadalmi státuszt nézve homogénné vált gettók kialakulása egy zsákutcába torkolló folyamat, amelynek számos lépcsőfoka van. A többségi társadalom által egyveretűnek tartott gettók társadalma a devianciák, a bűnözői szubkultúrák, a törvényen kívüli lét béklyóit egyformán magukon viselik. Függetlenül attól, hogy regionális, intraurbán elhelyezkedésük, társadalmi rétegzettségük, etnikai megosztottságuk tekintetében differenciált területi-társadalmi csoportokról van szó. A visszafordíthatatlan folyamat az adott településrész nagyságától, népességszámától, az ottani társadalom egyveretűségétôl, a kialakult gondok súlyosságától függóen előbb-utóbb öngerjesztővé válhat. Épp ezért a gettósodás mértékének súlyosbodása lehetetlen szigorú és következetes, a helyi adottságokat figyelembe vevő, egyrész centralizált, másrészt decentralizált felsőbb szakpolitikai intézkedések nélkül, ugyanis elkerülhetetlenül sérülnek az egyének, közösségek, önkormányzatok érdekei. Ennek ellenére hatvan év alatt jelentős állami, sôt, az elmúlt két évtizedben érkező Uniós pénzek felhasználásával, nagy apparátusok megmozgatásával annyit sikerült elérni, hogy a cigányság és a nyomorban élók néhány fokkal jobb lakáskörülmények között, de a többségi társadalom életszínvonalától távol, szinte azonos szeparációs szinten élnek, mint annakidején. Még mindig léteznek olyan gettók, ahol a lakhatással kapcsolatos intézkedések, rendelkezések vajmi kevés eredményt mutatnak. Ezekben a terekben idő kérdése a szociális robbanás, illetve 
megjósolhatatlan annak erőssége és hosszúsága. Leszakadó roncstársadalmaik láttán bizonyossá válik, hogy nem egy, hanem több párhuzamos valóság létezik Magyarországon és létezik egy „Másik Magyarország” is...

\author{
HaLÁsz LeVEnTE \\ Kodolányi János Egyetem, Budapest \\ halaszlevente@hotmail.com
}

\title{
IRODALOM
}

ANdORKa R.-Spéder Zs. 1994: Szegénység a 90-es évek elején. - In: Andorka R.-Kolosi T.-VuKOvich GY. (szerk.): Társadalmi riport 1994. TÁRKI, Budapest. pp. 74-106.

BERKI, M. 2016: Economic Restructuring and Social Polarisation in Kazincbarcika and its Region. - In: SzIRMAI V. (ed.): Artificial towns in the 21st Century. Hungarian Academy of Sciences Centre for Social Sciences Institute for Sociology, Budapest. pp. 217-244.

BoDnÁR, J. 2001: Fin de Millénaire Budapest. Metamorphoses of Urban Life. - University of Minnesota Press, Minneapolis. 222 p.

CAstells, M. 1995: La ciudad informacional. - Alianza Editorial, Madrid. 363 p.

Csite A.-KovÁch I. 2000: A falusi társadalom alakulása a rendszerváltozás folyamán - kézirat. Budapest.

Dobosy L. 2001: Ózd a XXI. század küszöbén. - Ceba, Budapest. 226 p.

Dobrossy I. 1993: A miskolci Avas. - In: Dobrossy I. (szerk.): Avas. Herman Ottó Múzeum, Borsodi Nyomda, Miskolc. pp. 69-80.

EGEDY T. 2000: Szegregáció és társadalmi kirekesztés a nagyvárosi lakótelepeken. - Földrajzi Közlemények 124. 48. pp. 93-109.

EgEDY T. (szerk.) 2005: Városrehabilitáció és társadalom. - MTA Földtudományi Kutatóintézet, Budapest. 305 p.

Ferge Zs. 2000: A társadalom pereme és az emberi méltóság. - Esély 1. pp. 42-48.

FERGE Zs. 2017: A magyar társadalom- és szociálpolitika (1990-2015). - Osiris, Budapest. 510 p.

GYURIS F. 2014: Az egyenlőtlen földrajzi fejlődés koncepciója. Földrajzi Közlemények 138. 4. pp. $293-305$.

HALÁsz L. 2018: Városfejlődési pályák és válságkezelési alternatívák. Miskolc, Ózd és Kazincbarcika rendszerváltozás utáni társadalmi, gazdasági és térszerkezeti átalakulása (doktori értekezés). - ELTE Földtudományi Doktori Iskola, Budapest. 271 p.

HalÁsz, L. 2016: Social and Economic Transformation in Komló and its Region. - In: SzIRMAI, V. (ed.): "Artificial Towns" in the 21st Century: Social Polarisation in the New Town Regions of East-Central Europe. Institute for Sociology Centre for Social Sciences Hungarian Academy of Sciences, Budapest. pp. 197-215.

Harvey, D. 1973: Social Justice and the City. - John Hopkins, Baltimore. 179 p.

JANKY B.-KEMÉNY I. 2004: Települési és lakásviszonyok. - Beszélő 9. 4. pp. 96-110.

JARY, D. - JARY, J. 1991: Collins Dictionary of Sociology. - Harper Collins, Glasgow. 750 p.

KARVAlics L. 1996: Magyarország városai. 1-2. kötet. - Égisz, Budapest. 522 p.

KEMÉNY I. 1972: Az alacsony jövedelmú népesség életkörülményei Magyarországon - kézirat. Budapest.

KEMÉNY I.-JANKY B.-LENGYEL G. (2004): A magyarországi cigányság. 1973-2003. - Gondolat, Budapest. 155 p. Kolosi T. 2000: A terhes babapiskóta. - Osiris, Budapest. 238 p.

KovÁch I. 2012: A vidék az ezredfordulón. A jelenkori magyar vidéki társadalom szervezeti és hatalmi változásai. - Argumentum, Budapest. 244 p.

LADÁNYI, J. 1991: Discrimination ethnique et auto-protection: le cas des tziganes de Miskolc. - Espaces et Sociétés 64. pp. 113-127.

LADÁNYI J.-VIRÁG T. 2009: A szociális és etnikai alapú lakóhelyi szegregáció változó formái Magyarországon a piacgazdaság átmeneti időszakában. - Kritika 2009. július-augusztus, pp. 1-19.

LADÁNYI J. 2012: Leselejtezettek. A kirekesztett népesség társadalom-és térszerkezeti elhelyezkedésének változása Magyarországon a piacgazdasági átmenet időszakában. - L’Harmattan, Budapest. 234 p.

LADÁNYI J.-SzELÉNYI I. 2014: Újrakasztosodás. - Élet és Irodalom 58. 38. 2014. szeptember 19.

LENGYEL G. 2009: Szilánkos mennyország. Szegénytelepek, cigánytelepek Miskolcon. - Beszélő Online 14. 7. http://beszelo.c3.hu/cikkek/szilankos-mennyorszag

LÓRÁNT K. 2017: Az acélváros végnapjai. - Antológia, Lakitelek. 257 p.

LosonCZI Á. 2005: Sorsba fordult történelem. - Holnap, Budapest. 329 p.

Miskolc Megyei Jogú Város Integrált Városfejlesztési Stratégia (2007-2013), 2008, Miskolc MJV Önkormányzata, Miskolc. 
Miskolc Megyei Jogú Város Településfejlesztési Stratégiája (2014-2020), 2013, Miskolc2020, Miskolc.

MoLDova Gy. (2017): Kegyelemkenyér. - Urbis, Budapest. 192 p.

Ózd Integrált Településfejlesztési Stratégia (2014-2020), 2015, ITS 2014 Konzorcium, Ózd.

Ózd Integrált Városfejlesztési Stratégia (2007-2013), 2008, Ózd Város Önkormányzata, Ózd.

Ózdi Esélyegyenlőségi Program, 2013, Ózd Város Önkormányzata, Ózd.

PÁsZTOR I.Z.-PÉNZES J. 2018: A cigányság lélekszáma és helyzete egy északkelet-magyarországi felmérés tükrében. Földrajzi Közlemények 142. 2. pp. 154-169.

RóBERT P. 2013: Társadalmi rétegek, osztályok vizsgálata a 2011. évi népszámlálás adata. - In: Statisztikai Szemle 91. 3. pp. 314-319.

SASSEN, S. 2000: Cities in a world economy. - Pine Forge Press, London. 182 p.

Sommer, R. 1969: Personal Space: The Behavioral Basis of Design. Englewood Cliffs, New Jersey. 273 p.

SPÉDER, Zs. (2000): Getting better and becoming dissimilar: economic well-being of the elderly in Hungary. In: StANOVNIK et al. (eds.): Economic well-being of the elderly: A comparison in five European countries. - Ashgate, Aldershot. pp. 53-97.

SPÉDER Zs. (2002): A szegénység változó arcai. - Andorka Rudolf Társadalomtudományi Társaság-Századvég, Budapest. 263 p.

SÝKORA, L. 2009: New socio-spatial formations: places of residential segregation and separation in Czechia. - Tijdschrift voor Economische en Sociale Geografie. 100. 4. pp. 417-435.

SzIRMAI V. 2019: Városok és városlakók. A befogadó és a kirekesztó városok. - Corvina Kiadó, Budapest. 340 p. ТóTH P. 1990: A miskolci cigánylakosság belső tagozódása. - Borsodi Szemle 35. 1. pp. 17-21.

VÁRADI M. M.-VIRÁG T. 2014: A térbeli kirekesztés változó mintái vidéki terekben. - Szociológiai Szemle 25. 1. pp. 89-113.

WACQuANT, L. 1999: Les Prisons de la misere. - Editions Raisons d'agir, Paris. 189 p.

WaCquant, L. (2004): What is a Ghetto? Constructing a Sociological Concept. - In: SMelser, N. J.-BAltes, P. B. (eds.): International Encyclopedia of the Social and Behavioral Sciences. Pergamon Press, London http://socialjustice.ccnmtl.columbia. edu/images/5/5d/Ghetto.pdf 